\title{
Uma história dos direitos da criança nos países lusófonos
}

\author{
A history of child's rights in Portuguese \\ speaking countries
}

Silvia Maria Favero Arend

Crianças dos países de língua portuguesa: histórias, culturas e direitos Verônica Regina Muller (org.) Maringá: Editora da Universidade Estadual de Maringá, 2011. 275 p.

O que há de comum na experiência de crianças e adolescentes que viveram em países lusófonos situados em quatro continentes do globo nas últimas décadas do século XX? De comum, segundo a educadora Verônica Regina Mül-

Silvia Maria Favero Arend é doutora em História pela Universidade Federal do Rio Grande do Sul e professora do Departamento de História da Universidade do Estado de Santa Catarina (smfarend@gmail.com).

Resenha recebida em 29 de junho e aprovada para publicação em 14 de agosto de 2012. 
ler, o fato de utilizarem o português como primeira ou segunda língua na vida cotidiana, as condições de pobreza que uma parcela significativa dessa população enfrenta ou, eventualmente, o acesso à educação escolar, mesmo que de forma precária. A obra, intitulada Crianças dos países de língua portuguesa: histórias, culturas e direitos, demonstra ainda, ao longo de seis capítulos, que há outro denominador comum. Desde a aprovação da Convenção Internacional dos Direitos da Criança pela Organização das Nações Unidas (ONU) em 1989, Angola, Brasil, Cabo Verde, Moçambique, Portugal e Timor Leste têm buscado, de diferentes maneiras e entre avanços e reveses, implementar a noção de direitos - sociais, civis e políticos - em favor de sua população infanto-juvenil. Essa tarefa exigiu (e continua a exigir) um esforço hercúleo do Estado, da sociedade civil, das famílias e dos indivíduos, uma vez que o processo de instituição da concepção de direitos humanos para os infantes de ambos os sexos implica grandes mudanças na esfera sociocultural, especialmente nas sociedades do continente africano.

As narrativas dessa faceta da história de crianças e adolescentes, com exceção do caso brasileiro, procuram dar conta, sobretudo, dos fenômenos ocorridos nos últimos trinta anos do século XX em cada sociedade em particular. Apesar de todos os textos se reportarem à história política dos Estados nacionais (processo de descolonização, independências e ditaduras/processos de democratização), os marcos temporais balizadores das análises são as legislações e/ou as políticas sociais instituídas, com ênfase nas relativas ao universo escolar. As narrativas são construídas a partir de dados obtidos através da análise do discurso de documentos de caráter oficial (em particular as legislações), etnografias, entrevistas e memórias. O ideário de infância e direitos humanos como discursos oriundos da sociedade ocidental e um olhar relativista em relação às noções de classe social, etnicidade e relações de gênero norteiam, do ponto de vista teórico, a escrita dos capítulos.

Além da História da Infância sob a ótica do nacional, os capítulos, em seu conjunto, descrevem um processo histórico transnacional, seja do ponto de vista dos usos do idioma português, seja do ponto de vista da transformação das crianças em sujeitos de direito. ${ }^{1} \mathrm{~A}$ junção dessas duas perspectivas no campo da história constitui, sem dúvida, o ponto forte do livro.

O capítulo sobre Angola, escrito por Eugênio Alves da Silva, é o único da obra que trata de crianças e adolescentes do meio rural. O autor justifica essa escolha porque, no período estudado, $42 \%$ da população do país habitavam no campo. Nessas localidades, meninos e meninas constituíam uma parcela im-

1. Sobre a História Transnacional, ver Bayly, C. A.; Beckert, Sven; Connelly, Matthew; Hofmeyr, Isabel; Kozol, Wendy; Seed, Patricia. AHR conversation: on Tansnational History, The American Historical Review, 1 dec. 2006, vol. $111, \mathrm{n}^{\circ} 5$, p. 1441-1464. 
portante da mão de obra familiar. A alfabetização através do idioma português na escola colocava em risco a "Educação Tradicional Africana" (ETA) (p. 47), especialmente a das meninas (p. 55). Para o autor, a resistência dos adultos das comunidades rurais à alfabetização no idioma português não está associada somente ao fato de ser a língua do antigo colonizador, mas a rupturas significativas, reproduzidas sobretudo no âmbito das relações de trabalho e das relações de gênero.

No capítulo sobre o Brasil, Verônica Regina Müller, Miryam Mage e Ailton José Morelli procuram fornecer aos leitores e leitoras um panorama da introdução dos direitos da criança e do adolescente no país durante todo o século XX. Nessa narrativa histórica, a ênfase recai sobre os avanços obtidos no período pós-Estatuto da Criança e do Adolescente. A partir de 1990, as políticas sociais, sobretudo as de cunho compensatório (bolsa família), possibilitaram que muitas crianças e adolescentes que habitavam nas cidades e no campo não se evadissem dos bancos escolares e tivessem um maior domínio do idioma português (p. 96). Para os autores, porém, ainda há muito a fazer no campo dos direitos. Entre as demandas, as mais difíceis de vencer são as de caráter adultocêntrico, presentes na sociedade brasileira (p. 93).

Os capítulos sobre Cabo Verde, produzido por Lorenzo I. Bordonaro e Redy Wilson Lima, e sobre Moçambique, por Elena Colona e Eugénio José Brás, discutem fenômenos da mesma natureza: os embates existentes entre os discursos relativos aos diferentes modos de ser criança e adolescente no mundo urbano daqueles países nos últimos trinta anos do século XX. Enquanto a noção de infância afirma que o "espaço esperado" para a criança e o adolescente é a escola e/ou o ambiente doméstico, as famílias pobres das cidades de Praia e Maputo mantiveram a prática de deixar seus filhos e filhas brincando/trabalhando pelas ruas das cidades. Lorenzo I. Bordonaro e Redy Wilson Lima entendem que há uma grande diferença entre "crianças de rua e crianças na rua", na zona urbana de Cabo Verde (p. 127). Afirmam, de forma crítica, que conceitos aplicados por técnicos das agências internacionais, operadores do direito e jornalistas não dizem respeito às realidades africanas, mas se limitam às latino-americanas. Os autores não concordam com a transformação do modo de ser criança "tradicional" em um problema social, especialmente pela mídia. Já para Elena Colona e Eugénio José Brás, o deslocamento dos menores pelas ruas da cidade de Maputo está de longa data associado a estratégias de sobrevivência das famílias empobrecidas (p. 171).

Para Catarina Tomás, Natalia Fernandes e Manuel Jacinto Sarmento, a história dos direitos da criança em Portugal, desde o processo de redemocratização do país, em 1974, tem como marca os paradoxos. Se, por um lado, o país atingiu excelentes índices no campo da saúde infantil e expandiu a proteção aos menores de idade através da justiça, por outro, a violência doméstica ainda conti- 
nuou presente entre as famílias; além disso, a taxa de natalidade decresceu bastante, e crescimento populacional, se houve, foi por conta da imigração. Os autores mencionam mais dois problemas relativos ao universo infantil que emergiram no período: a obesidade e o stress (p. 219).

O último capítulo procura historiar a introdução dos direitos da criança na "fraturada" sociedade do Timor Leste. Afonso Maia, Benvinda L. da R. Oliveira, Márcia Valdineide Cavalcante e Silvestre de Oliveira descrevem as diferenças em relação a esse processo em três períodos distintos da história daquela sociedade durante o século XX: o período da dominação colonial portuguesa (1515-1975), a época da "invasão" indonésia (1975-1999) e o pós-independência do país, em 2002. Os autores e autoras consideram fundamental, nos três períodos, o direito à vida, à educação e à saúde. Ressaltam, também, que o domínio dos idiomas português e, depois, indonésio, pelas crianças e adolescentes, tinha o poder de produzir a inclusão ou a exclusão social naquela sociedade (p. 246).

Esses processos históricos nos países lusófonos poderão, certamente, ser interpretados de muitas outras maneiras. Esta, todavia, cativa os leitores e leitoras pelo seu ineditismo no campo da História da Infância e da História Transnacional e por fornecer pistas para outras investigações. Estudos desta natureza devem ser feitos para que, além de produzir conhecimento, possamos constatar que outros “mundos" podem ser construídos. 